\title{
FAKTOR YANG MEMPENGARUHI KEJADIAN INFEKSI SALURAN PERNAFASAN AKUT (ISPA) DI PROVINSI BENGKULU
}

\begin{tabular}{ll}
\multicolumn{1}{c}{$\begin{array}{c}\text { Sri Haryani }{ }^{1} \text {, Misniarti } \\
\text { 1'Jurusan Keperawatan, Politeknik Kesehatan Kementerian Kesehatan Bengkulu, Indonesia }\end{array}$} \\
\hline Info Artikel & Abstrak \\
\hline Genesis Naskah : & ISPA (Infeksi Saluran Pernafasan Akut) merupakan penyakit infeksi akut yang menyerang \\
& salah satu bagian atau lebih saluran pernafasan. Penelitian ini bertujuan untuk mengetahui \\
Submission: $21-04-2021$ & faktor apa saja yang menyebabkan angka kejadian penyakit ISPA pada balita meningkat. \\
Revised: $29-11-2021$ & Desain penelitian yang digunakan adalah desain penelitian observasi, penelitian dengan \\
Accepted: $26-11-2021$ & menggunakan desain crossectional. Sampel 44 anak balita dengan total sampling. Hasil \\
& penelitian menunjukkan bahwa faktor status imunisasi yang didapatkan oleh balita \\
& merupakan faktor dominan yang mempengaruhi kejadian ISPA. Penelitian ini \\
direkomendasikan untuk dilakukannya penyuluhan kesehatan tentang pencegahan ISPA & pada balita secara berkala oleh tenaga kesehatan dan kader kesehatan.
\end{tabular}

Lingkungan, status imunisasi,

ISPA, balita.

\section{FACTORS AFFECTING THE INCIDENCE OF ABOVE RESPIRATORY CHANNEL INFECTION (ARI) IN WORKING AREA OF PUSKESMAS PERUMNAS}

Keywords:
Environment,immunization
status, ARI, toddler

status, ARI, toddler

\begin{abstract}
ARI (Acute Respiratory Infection) is an acute infectious disease that attacks one or more respiratory tracts. This study aims to determine what factors cause the incidence of ARI in infants to increase. The research design used was an analytic observational research design using a cross-sectional design. Sample 44 children under five with total sampling. The results showed that the factors of immunization status obtained by toddlers were the dominant factors affecting ARI. This research is recommended to conduct regular health education by health workers and health cadres.
\end{abstract}




\section{Pendahuluan}

Menurut WHO (2007), ISPA menjadi salah satu penyebab utama morbiditas dan mortalitas penyakit menular di dunia. Hampir empat juta orang meninggal akibat ISPA setiap tahun, 98\%nya disebabkan oleh infeksi saluran pernapasan bawah. Kelompok yang paling berisiko adalah balita, anak-anak, dan orang lanjut usia, terutama di negara-negara dengan pendapatan per kapita rendah dan menengah.

ISPA (Infeksi Saluran Pernafasan Akut) merupakan penyakit infeksi akut yang menyerang salah satu bagian atau lebih dari saluran nafas mulai dari hidung (saluran atas) hingga alveoli (saluran bawah) termasuk jaringan adneksanya seperti sinus, rongga telinga tengah dan pleura (Irianto, 2015). Menurut Maharani, dkk (2013), ada banyak faktor yang dapat menyebabkan ISPA, kejadian ISPA dipengaruhi oleh agen penyebab seperti virus dan bakteri, faktor pejamu ( usia anak, jenis kelamin, status imunisasi, pendidikan orang tua, dan pekerjaan orang tua) serta keadaan lingkungan (ventilasi, suhu, kelembapan, dan jumlah hunian). Usia anak merupakan faktor predisposisi utama yang menentukan tingkat keparahan serta luasnya infeksi saluran nafas. Keadaan lingkungan tempat tinggal juga mempengaruhi terjadinya penyakit ISPA, pada anak-anak yang tinggal dirumah dengan ventilasi baik, insiden ISPA lebih rendah dibanding anak balita yang tinggal di rumah berventilasi buruk.

Menurut Murti (2016), bahwa tingkat kejadian ISPA banyak ditemukan pada anak balita dengan jenis kelamin laki-laki yaitu sebesar 57,5\% dan pada anak balita jenis kelamin perempuan yaitu 42,5\%, dan menurut Angelina (2012), bahwa 56,8\% ventilasi rumah anak balita yang mengalami ISPA memenuhi syarat atau baik, sedangkan 43,2\% merupakan ventilasi rumah anak balita dengan ISPA yang tidak memenuhi syarat. Penyakit ISPA dapat berupa batuk, kesulitan bernafas, sakit tenggorokan, pilek, demam dan sakit kepala. Namun sebagian anak yang menderita radang paru (pneumonia), bila infeksi paru ini tidak diobati dengan antibiotik akan menyebabkan kematian (Fuad, 2008).

(C) PoltekkesKemenkes Jakarta I

Jl. WijayaKusuma No. 47-48 Cilandak Jakarta Selatan, Indonesia email: jurnalquality@poltekkesjakarta1.ac.id
Balita umur 1->3 tahun merupakan kasus terbanyak dengan jumlah 151 kasus $(41,25 \%)$, jenis kelamin laki-laki 185 kasus $(50,54 \%)$, berdasarkan berat badan $10 \mathrm{~kg}-<16 \mathrm{~kg}$ sebanyak 258 kasus (70,51\%) (Maakh, dkk 2015). Infeksi Saluran Pernapasan Akut (ISPA) di Indonesia, selalu menempati urutan pertama penyebab kematian pada kelompok bayi dan balita (Riskesdas, 2018). Data di provinsi Bengkulu tahun 2017 kasus ISPA didapatkan sebesar 2052 (Profil Kesehatan Provinsi Bengkulu, 2017). Di Kabupaten Rejang Lebong tahun 2018 angka kasus ISPA sebesar 1241 orang (Dinkes Rejang Lebong, 2018), pada tahun 2019 yaitu 356 kasus, ISPA selalu masuk kedalam 10 besar daftar penyakit yang ada di puskemas Perumnas dan menempati peringkat pertama penyakit terbanyak diderita masyarakat (Buku Register Puskesmas Perumnas, 2019).

Angka ISPA yang tinggi juga diamati di antara 41,36\% anak-anak yang tinggal di rumah tangga yang menggunakan bahan bakar kayu bakar, $35,04 \%$ anak-anak dengan hewan peliharaan dalam rumah tangga, $34,82 \%$ anak-anak dengan pertumbuhan lambat, $53,85 \%$ anak-anak dengan tingkat IV dan $66,67 \%$ anak-anak dengan malnutrisi grade V. Kejadian ISPA lebih banyak terjadi selama bulan-bulan musim dingin setiap tahun (bulan Oktober - Januari) serta anak-anak dengan riwayat keluarga penyakit pernapasan (Ramani dkk, 2014). Pengurangan secara drastis dalam kejadian ISPA melalui intervensi dengan mencuci tangan, menyusui, ketersediaan berbagai diagnostik yang cepat dan layak, serta pengenalan vaksin pentavalen di bawah Jadwal Imunisasi Nasional yang sedang berlangsung diperlukan untuk pengurangan ISPA (Selvaraj dkk, 2014).

Hasil wawancara yang dilakukan pada Sabtu, 5 Januari 2019 terhadap beberapa ibu yang memiliki anak sedang mengalami ISPA, bahwa anak mereka sudah mengalami ISPA sudah lama dan sering, mereka juga sudah membawa anaknya berobat ke puskesmas, tetapi sembuh sebentar dan sakit batuk pilek kembali. Mereka juga mengatakan bahwa jika anak sakit batuk pilek disertai dengan demam panas dan tidak nafsu makan. Berdasarkan fenomena diatas, maka penulis tertarik untuk melakukan penelitian tentang apa saja "Faktor yang Mempengaruhi Kejadian ISPA pada Anak Balita" yang bertujuan untuk mengetahui

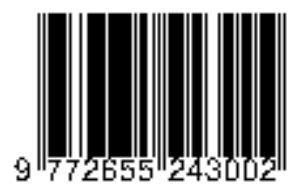


faktor apa saja yang menyebabkan angka kejadian penyakit ISPA pada balita meningkat di wilayah kerja Puskesmas Perumnas Kabupaten Rejang Lebong tahun 2019.

\section{Metode}

Desain penelitian yang digunakan adalah desain penelitian observasi dengan menggunakan desain crossectional (Dharma, 2012). Penelitian ini dilakukan diwilayah kerja Puskesmas Perumnas Kabupaten Rejang Lebong Tahun 2019. Peneliti akan melakukan observasi terhadap ibu-ibu yang memiliki anak yang menderita ISPA untuk diketahui sejauh mana pengetahuan dan perawatan mereka dirumah pada anak balita, untuk mengetahui hubungana antara variabel independent dan variabel dependent yang di identifikasi pada satu satuan waktu yang sama.

\section{Hasil}

Berdasarkan tabel 4.1 diketahui bahwa lebih dari separuh responden pada rentang usia balita 59 ,' $1 \%$, sebagian besar berjenis kelamin laki-laki $68,2 \%$, lebih dari separuhnya berpendidikan tinggi $90,9 \%$, lebih dari separuhnya orang tua bekerja $84,1 \%$, lebih dari separuhnya memiliki status imunisasi lengkap 75,0\%.

Tabel 4.1 Distribusi Karakteristik Responden Berdasarkan Usia Balita, Jenis Kelamin, Balita, Pendidikan Orang Tua, Pekerjaan Orang Tua Dan Status Imunisasi Balita Dengan ISPA Di Wilayah Kerja Puskesmas Perumnas Tahun $2019(\mathrm{~N}=44)$

\begin{tabular}{|c|l|c|c|}
\hline No & Variabel & Jumlah $(\mathbf{n}=\mathbf{4 4})$ & Persen $(\%)$ \\
\hline 1. & Umur (\%) & 18 & \\
& Minimum & 26 & 40,9 \\
& Maksimum & 22 & 59,1 \\
& Rata-rata & 14 & \\
\hline 2. & JenisKelamin & 30 & 31,8 \\
& Perempuan & & 68,2 \\
& Laki-laki & 4 & 9,1 \\
\hline 3. & Pendidikan & 40 & 90,9 \\
& Rendah & & \\
& Tinggi & &
\end{tabular}

(C) PoltekkesKemenkes Jakarta I

J1. WijayaKusuma No. 47-48 Cilandak Jakarta Selatan, Indonesia email: jurnalquality@poltekkesjakarta1.ac.id

\begin{tabular}{|c|l|c|c|}
\hline 4. & Pekerjaan & 37 & 84,1 \\
& Bekerja & 7 & 15,9 \\
\hline
\end{tabular}

Tabel 4.2 dibawah ini menunjukkan bahwa lebih dari separuh 56,6\% responden bertempat tinggal dilingkungan yang baik dan hampir seluruh responden memiliki status imunisasi lengkap $90,1 \%$.

Tabel 4.2 Distribusi Lingkungan Tempat Tinggal Keluarga dan Status Imunisasi Balit Tentang Kejadian ISPA di Wilayah Kerja Puskesmas Perumnas Tahun $2019(n=44)$

\begin{tabular}{|c|l|c|c|}
\hline No & \multicolumn{1}{|c|}{ Variabel } & $\begin{array}{c}\text { Jumlah } \\
(\mathrm{n}=44)\end{array}$ & Persen (\%) \\
\hline 1. & Lingkungan & & \\
& Baik & 25 & 56,8 \\
& Tdk Baik & 19 & 43,2 \\
\hline 2. & Status Imunisasi & & \\
& Lengkap & 33 & 75,0 \\
& Tdk Lengkap & 11 & 25,0 \\
\hline
\end{tabular}

Tabel 4.3 di bawah ini menunjukkan bahwa responden balita yang mengalami ISPA memiliki lingkungan tempat tinggal baik 90,1\% dibandingkan dengan balita yang tidak mengalami ISPA $77,3 \%$. Hasil uji statistik $\left(\chi^{2}\right)$ di dapatkan $p$ value 0,000 dengan nilai OR 4,6 (CI 95\%;2,1;2,7), artinya ada hubungan bermakna antara lingkungan dengan kejadian ISPA di wilayah Kerja Puskesmas Perumnas. Balita yang memiliki lingkungan tempat tinggal yang tidak baik mempunyai peluang empat koma lima lima kosong untuk mengalami ISPA dibandingkan dengan balita yang memiliki tempat tinggal yang baik.

Tabel 4.3 Hubungan Lingkungan Dengan Kejadian ISPA Di Wilayah Kerja Puskesmas Perumnas Kabupaten Rejang Lebong Provinsi Bengkulu Tahun 2019 ( $\mathrm{N}=44)$

\begin{tabular}{|c|c|c|c|c|c|c|c|c|}
\hline \multirow{3}{*}{$\begin{array}{c}\text { Ling } \\
\text { kung } \\
\text { an }\end{array}$} & \multicolumn{4}{|c|}{ ISPA } & \multirow{2}{*}{\multicolumn{2}{|c|}{ Total }} & \multirow{2}{*}{$\begin{array}{c}\text { OR } \\
(95 \% \\
\text { CI })\end{array}$} & \multirow[t]{3}{*}{$p$} \\
\hline & \multicolumn{2}{|c|}{$\mathrm{Ya}$} & \multicolumn{2}{|c|}{ Tidak } & & & & \\
\hline & $\mathrm{n}$ & $\%$ & $\mathrm{n}$ & $\%$ & $\mathrm{n}$ & $\%$ & & \\
\hline Baik & 40 & $\begin{array}{l}90, \\
1\end{array}$ & 34 & 77,3 & 74 & $\begin{array}{c}84, \\
1\end{array}$ & $\begin{array}{c}4,550 \\
(2,1- \\
2,7)\end{array}$ & $\begin{array}{c}0, \\
00 \\
0\end{array}$ \\
\hline $\begin{array}{l}\text { Tdk } \\
\text { baik }\end{array}$ & 4 & 9,1 & 10 & 22,7 & 14 & $\begin{array}{c}15 \\
9\end{array}$ & & \\
\hline
\end{tabular}

Tabel dibawah menunjukkan bahwa balita yang mengalami ISPA memiliki status imunisasi baik $56,8 \%$, dibandingkan dengan balita yang memiliki status imunisasi tidak lengkap $75 \%$. Hasil uji statistik $\left(\chi^{2}\right)$ didapatkan nilai $p$ value 0,03 dengan

ISSN 2655-2434

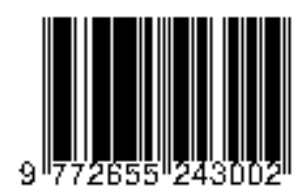


nilai OR 2,5 (CI 95\%;1,1;5,1), artinya ada hubungan bermakna antara kejadian ISPA dengan status imunisasi balita, dimana balita yang mendapatkan imunisasi tidak lengkap mempunyai peluang tiga kali untuk mengalami ISPA dibandingkan dengan balita yang mendapatkan imunisasi lengkap.

Analisis multivariat dalam penelitian ini menggunakan pemodelan regresi logistik sebagai pemodelan faktor resiko. Analisis ini digunakan untuk mengetahui variabel independen (lingkungan dan status imunisasi) yang paling berhubungan dengan variabel dependen (kejadian ISPA) setelah dikontrol dengan variabel perancu (usia, jenis kelamin, pendidikan, pekerjaan). Uji multivariat dengan regresi logistik dilakukan beberapa tahap, seperti pada berikut ini:

Langkah pertama yang dilakukan pada analisis multivariat ini adalah melakukan seleksi pada setiap variabel yang dapat masuk dalam analisis multivariat (pemodelan) melalui seleksi bivariat dengan menggunakan regresi logistik dengan syarat nilai $p$ value $>0,25$ antara lingkungan rumah dan status imunisasi dengan kejadian ISPA. Variabel yang memiliki nilai $p$ kurang dari 0,25 akan dilanjutkan dalam analisis multivariat, sedangkan variabel dengan nilai $p$ lebih besar dari 0,25 tidak dimasukkan dalam analisis multivariat.

Table 4.4 Hubungan Status Imunisasi Dengan Kejadian ISPA Di Wilayah Kerja Puskesmas Perumnas Kabupaten Rejang Lebong Provinsi Bengkulu Tahun 2019 (N=44)

\begin{tabular}{|c|c|c|c|c|c|c|c|c|}
\hline \multirow{3}{*}{$\begin{array}{c}\text { Status } \\
\text { Imunis } \\
\text { asi }\end{array}$} & \multicolumn{4}{|c|}{ ISPA } & \multirow{2}{*}{\multicolumn{2}{|c|}{ Total }} & \multirow{3}{*}{$\begin{array}{c}\mathrm{OR} \\
(95 \% \\
\mathrm{CI}) \\
\end{array}$} & \multirow[t]{3}{*}{$p$} \\
\hline & \multicolumn{2}{|c|}{$\mathrm{Ya}$} & \multicolumn{2}{|c|}{ Tidak } & & & & \\
\hline & $\mathrm{N}$ & $\%$ & $\mathrm{n}$ & $\%$ & $\mathrm{n}$ & $\%$ & & \\
\hline $\begin{array}{l}\text { Lengk } \\
\text { ap }\end{array}$ & 25 & 56,8 & 33 & 75 & 58 & 65,9 & $\begin{array}{c}2,47 \\
(1,1- \\
5,1)\end{array}$ & $\begin{array}{c}0, \\
02 \\
6\end{array}$ \\
\hline $\begin{array}{l}\text { Tdk } \\
\text { lengk } \\
\text { ap }\end{array}$ & $\begin{array}{l}1 \\
9\end{array}$ & $\begin{array}{c}43, \\
2\end{array}$ & $\begin{array}{l}1 \\
1\end{array}$ & $\begin{array}{l}2 \\
5\end{array}$ & $\begin{array}{l}3 \\
0\end{array}$ & $\begin{array}{c}34, \\
1\end{array}$ & & \\
\hline
\end{tabular}

Hasil seleksi bivariat dari setiap variabel dapat dilihat pada tabel berikut ini:

Tabel 4.5 Seleksi Bivariat antara Kejadian ISPA di Wilayah Kerja Puskesmas Perumnas Kabupaten Rejang Lebong Provinsi Bengkulu Tahun $2019(n=44)$

(C) PoltekkesKemenkes Jakarta I

Jl. WijayaKusuma No. 47-48 Cilandak Jakarta Selatan, Indonesia email: jurnalquality@poltekkesjakarta1.ac.id

\begin{tabular}{|l|l|}
\hline \multicolumn{1}{|c|}{ Variabel } & p \\
\hline Lingkungan & $0,000^{*}$ \\
\hline Status imunisasi & $0,026^{*}$ \\
\hline \multicolumn{2}{|c|}{ bermakna pada $\alpha=0,25$}
\end{tabular}

Berdasarkan tabel 4.5 diketahui bahwa ada satu variabel yang mempunyai nilai $p$ kurang dari 0,25 , yaitu lingkungan $(p=0,000)$. Hal ini berarti bahwa variabel lingkungan tidak dapat diikutkan kedalam analisis multivariat.

Langkah kedua dari analisis multivariat adalah pemodelan multivariat dengan cara menganalisis variabel lingkungan dan status imunisasi yang berhubungan dengan variabel kejadian ISPA. Hasil analisis yang memiliki nilai $p$ kurang dari $\alpha(0,05)$ dimasukkan dalam pemodelan multivariat, sedangkan variabel yang mempunyai nilai $p$ lebih besar dari $\alpha(0,05)$ dikeluarkan dari pemodelan. Pengeluaran variabel dari model dilakukan satu persatu, dimulai dari yang memiliki nilai $p$ yang terbesar. Hasil uji dapat dilihat pada tabel berikut:

Tabel 4.6 Pemodelan Multivariat antara Kejadian ISPA Di Wilayah Kerja Puskesmas Perumnas Kabupaten Rejang Lebong Provinsi Bengkulu Tahun 2019 ( $\mathrm{N}=44)$

\begin{tabular}{|l|c|c|c|c|c|}
\hline $\begin{array}{c}\text { Variabel } \\
\text { Independen }\end{array}$ & $\mathbf{B}$ & $\mathbf{P}$ & $\mathbf{O R}$ & \multicolumn{2}{|c|}{$\begin{array}{c}\text { O5\% CI for } \\
\text { EXP(B) }\end{array}$} \\
\cline { 4 - 6 } & & & & $\begin{array}{c}\text { Lowe } \\
\text { r }\end{array}$ & Upper \\
\hline Lingkungan & 1,114 & 0,006 & 3,047 & 1,37 & 6,775 \\
Status & 0,655 & ${ }^{*}$ & 1,925 & 1 & 4,298 \\
Imunisasi & - & 0,110 & 1,602 & 0,86 & 2 \\
Constanta & 1,536 & 0,000 & & 2 & \\
\hline
\end{tabular}

Pada tabel 4.6 terlihat ada satu variabel yang memiliki nilai $p$ value $<0,05$ yaitu lingkungan $(p=0,006)$. Tahap selanjutnya tidak terdapat lagi variabel dengan nilai $p$ value $>0,005$, sehingga variabel status imunisasi langsung dapat dilakukan uji interaksi.

Berdasarkan tabel 4.7 diatas menunjukkan bahwa tidak ada interaksi antara lingkungan tempat tinggal dengan kejadian ISPA ( $p=>0,597 ; \alpha=0,05)$.

Tabel 4.7 Uji Interaksi antara Kejadian ISPA di Wilayah Kerja Puskesma Perumnas Kabupaten

ISSN 2655-2434

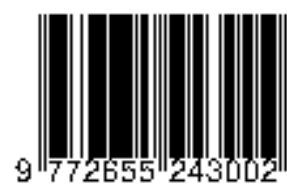


Rejang Lebong Provinsi Bengkulu Tahun 2019 $(n=44)$

\begin{tabular}{|l|l|l|l|l|l|}
\hline \multirow{2}{*}{ Variabel } & \multirow{2}{*}{ B } & \multirow{2}{*}{ P } & \multirow{2}{*}{ OR } & \multicolumn{2}{|c|}{$\begin{array}{c}\text { 95\% CI for } \\
\text { EXP(B) }\end{array}$} \\
\cline { 4 - 6 } & & & & Lower & Upper \\
\hline $\begin{array}{l}\text { Lingkung } \\
\text { Kejadin }\end{array}$ & 0,432 & 0,597 & 1,540 & 0,310 & 7,645 \\
$\begin{array}{l}\text { ISPA } \\
\text { Constant }\end{array}$ & 1,099 & 0,007 & 0,333 & & \\
& & & & & \\
\hline
\end{tabular}

Uji konfounding antara variabel independen dan konfounding dengan variabel dependen dengan cara melihat nilai OR untuk variabel utama dengan dikeluarkannya variabel kandidat konfounding, bila perubahannya $>10 \%$, maka variabel tersebut dianggap sebagai variabel konfounding. Uji tersebut dapat dilihat pada tabel berikut:

Tabel 4.8Uji Konfonding antara Kejadian ISPA di Wilayah Kerja Puskesmas Perumnas Kabupaten Rejang Lebong Provinsi Bengkulu Tahun 2019 (n=44)

\begin{tabular}{|l|c|c|c|c|c|}
\hline \multicolumn{1}{|c|}{ Variabel } & B & P & OR & \multicolumn{2}{c|}{ 95\% CI EXP(B) } \\
& & & & \multicolumn{2}{c|}{} \\
\cline { 4 - 6 } & & & & Lower & $\begin{array}{c}\text { Uppe } \\
\text { r }\end{array}$ \\
\hline Lingkungan & 1,279 & 0,004 & 3,593 & 1,517 & 8,509 \\
Status Imunisasi & 1,586 & 0,000 & 4,884 & 2,011 & 11,86 \\
Usia Balita & $-0,624$ & 0,058 & 0,536 & 0,281 & 5 \\
Jenis Kelamin & $-0,790$ & 0,190 & 0,454 & 0,139 & 1,021 \\
Balita & 0,229 & 0,695 & 1,258 & 0,400 & 1,479 \\
Pekerjaan Orang & 0,978 & 0,030 & 2,660 & 1,098 & 3,960 \\
Tua & & & & & \\
$\begin{array}{l}\text { Pendidikan } \\
\text { Orang Tua }\end{array}$ & $-0,033$ & 0,976 & 1,968 & & 6,443 \\
Constant & & & & & \\
\hline
\end{tabular}

Berdasarkan tabel 4.8 uji konfounding diatas, ada tiga variabel yang memiliki nilai $p<0,05$ yaitu lingkungan $(p=0,008)$ dan status imunisasi $(p=0,000)$.

Analisis multivariat terakhir yang dilakukan adalah dengan melakukan interpretasi semua variabel yang bermakna (lingkungan dan status imunisasi) seperti dapat dilihat pada tabel berikut:

Tabel 4.9 Hasil Pemodelan Multivariat Terakhir Antara Kejadian ISPA di Wilayah Kerja Puskesmas Perumnas Kabupaten Rejang Lebong Provinsi Bengkulu Tahun 2019 (n=44)

\begin{tabular}{|c|c|c|c|c|}
\hline Variabel & B & P & OR & $\begin{array}{c}\text { 95\% CI for } \\
\text { EXP(B) }\end{array}$ \\
& & & & \\
\hline
\end{tabular}

(C) PoltekkesKemenkes Jakarta I

Jl. WijayaKusuma No. 47-48 Cilandak Jakarta Selatan, Indonesia email: jurnalquality@poltekkesjakarta1.ac.id

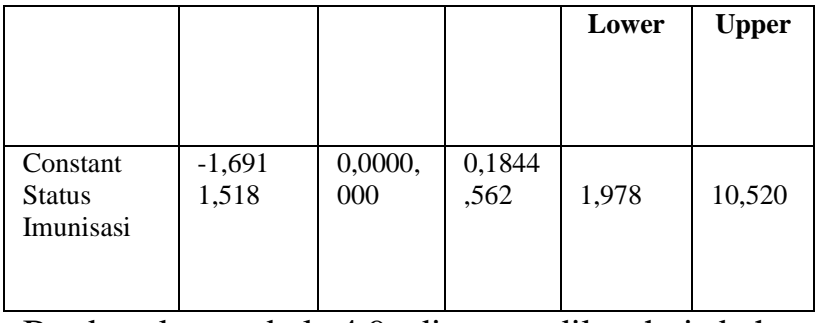

Berdasarkan tabel 4.9 di atas diketahui bahwa variabel yang berhubungan secara bermakna dengan kejadian ISPA adalah status imunisasi setelah dikontrol variabel lingkungan sebesar 1,9\%.

\section{Faktor Demografi dan Biologis Yang Berkontribusi Terhadap Kejadian ISPA}

Hasil penelitian tentang karakteristik menunjukkan bahwa tingkat kejadian ISPA diwilayah kerja Puskesmas Perumnas berdasarkan umur, paling banyak ditemukan pada umur 1- 5 tahun yaitu $59,1 \%$, hal ini menunjukkan bahwa tingkat kejadian infeksi saluran pernafasan akut banyak dialami pada umur 1-5 tahun. Hasil ini sesuai dengan Marlina (2014) bahwa berdasarkan umur, paling banyak ditemukan pada golongan umur $\geq 12-36$ bulan yaitu $58 \%$, kemudian pada golongan umur $<36-\leq 60$ bulan yaitu $42 \%$. Menurut Fitriawati (2013) dalam Maharani (2013), dari hasil penelitian yang didapat tingkat kejadian ISPA pada balita paling sering terjadi pada anak balita dengan umur $12-<60$ bulan sering terjadi yaitu $67,4 \%$ dan pada anak balita umur $0-<12$ bulan yaitu sebesar 33,6\%, karena pada usia tersebut anak sudah banyak terpapar dengan lingkungan luar dan kontak dengan penderita ISPA lainnya sehingga memudahkan anak untuk menderita ISPA.

Berdasarkan karakteristik hasil penelitian menunjukkan bahwa anak balita diwilayah Puskesmas Perumnas menunjukkan kejadian ISPA banyak dialami oleh jenis kelamin laki-laki yaitu 68,2\%, hal ini sesuai dengan Marlina (2014) yang menyatakan bahwa proporsi anak balita berdasarkan jenis kelamin yang banyak ditemukan mengalami ISPA yaitu jenis kelamin laki-laki sebesar 52\%, sedangkan pada anak balita perempuan yang mengalami ISPA yaitu $38 \%$. Pada penelitian tentang Faktor Resiko Kejadian ISPA pada balita, menurut Murti (2016) bahwa tingkat kejadian ISPA banyak dialami oleh anak balita dengan jenis kelamin laki-laki yaitu sebesar 57,5\%

ISSN 2655-2434 
dan pada anak balita jenis kelamin perempuan yaitu $42,5 \%$. Jenis kelamin laki-laki menyumbang $54,4 \%$ menjadi penyebab terjadinya ISPA pada anak balita (Odu et al, 2018). Jenis kelamin lakilaki menjadi penyumbang terbesar angka kejadian ISPA ini karena adanya perbedaan perilaku dan anak laki-laki lebih banyak menghabiskan waktu diluar rumah sehingga resiko kontak dengan agen penyakit lebih tinggi dibandingkan anak perempuan. Selanjutnya, dapat dilihat dari kepedulian terhadap kesehatan, perempuan lebih peduli jika dalam kondisi sakit dibandingkan lakilaki sehingga jika terkena suatu penyakit, perempuan akan lebih peduli dengan prosedur pengobatan dibandingkan laki-laki.

Status pendidikan orang tua di wilayah kerja Puskesmas Perumnas yang banyak mengalami ISPA adalah dengan pendidikan orang tua yang tinggi yaitu 90,9\% sedangkan pendidikan yang rendah yaitu 9,1\%. Menurut Ujunwa (2014) salah satu faktor terjadinya ISPA pada anak balita adalah pendidikan ibu yang rendah, ini sesuai dengan Tazinya et al, (2018), bahwa pendidikan ibu yang rendah menjadi salah satu penyebab terjadinya ISPA. Hal ini sejalan dengan Ramezanil et al, (2015) bahwa pendidikan ibu yang rendah menjadi salah satu penyebab terjadinya ISPA pada balita, sedangkan Ibu yang buta huruf di negara berkembang menjadi penyebab utama terjadinya ISPA pada anak balita (Rehman, 2018). Pendidikan menjadi salah satu faktor penyebab terjadinya ISPA karena dengan ibu dan ayah yang memiliki pendidikan tinggi diharapkan dapat memiliki pengetahuan yang baik tentang cara perawatan anak balita saat mengalami ISPA dirumah, sehingga kejadian ISPA akan menurun. Pendidikan Ibu sangat erat kaitannya dengan kesehatan keluarga. Ibu pada umumnya berperan utama dalam pemeliharaan kesehatan bayi dan balita dirumah. Semua upaya akan dilakukan agar anak tetap sehat. Ibu dengan pendidikan baik akan mempunyai wawasan yang cukup dalam pemeliharaan kesehatan anaknya.

Hasil karakteristik penelitian juga menunjukkan tingkat kejadian ISPA di wilayah kerja Puskesmas Perumnas sebagian besar dialami oleh anak balita dengan orang tua yang bekerja yaitu $84,1 \%$, sedangkan pada anak balita dengan orang tua yang tidak bekerja yaitu $15,9 \%$, ini sesuai

(C) PoltekkesKemenkes Jakarta I

Jl. WijayaKusuma No. 47-48 Cilandak Jakarta Selatan, Indonesia email: jurnalquality@poltekkesjakarta1.ac.id dengan hasil penelitian yang dilakukan oleh Geberetsadik et al, (2015) bahwa anak balita yang memiliki ayah dan ibu yang bekerja merupakan penyebab anak mengalami ISPA. Ini menunjukkan bahwa kejadian ISPA banyak dialami pada anak balita dengan orang tua yang bekerja karena dengan orang tua yang sibuk bekerja kebersihan anak saat bermain dan bersosialisasi dengan lingkungan dan teman sebayanya tidak terjaga dengan baik akibat kesibukan orang tua dalam bekerja. Salah satu jenis pekerjaan yang mempunyai hubungan erat dengan penyakit akibat pekerjaan seperti : kecelakaan kerja, keracunan, silikosis, asbestosis dan lain-lain Marni (2014).

Berdasarkan status pemberian imunisasi pada anak balita yang banyak mengalami ISPA yaitu yang memiliki imunisasi lengkap sebesar 75\% dan anak balita dengan imunisasi tidak lengkap yaitu 25\%. Menurut Marlina dkk (2014), proporsi anak balita yang mengalami ISPA berdasarkan status imunisasi paling banyak dialami pada anak balita dengan status imunisasi lengkap yaitu $71 \%$ dan dengan status imunisasi tidak lengkap yaitu $29 \%$ anak balita. Pemberian imunisasi yang tidak lengkap juga mempengaruhi terjadinya ISPA (Ujunwa, 2014). Dengan pemberian imunisasi saat anak balita dengan lengkap diharapkan status imun anak akan baik sehingga tidak mudah untuk terserang penyakit yang disebabkan oleh penurunan status imun. Menurut Depkes RI (2012), pemberian immunisasi sangat diperlukan baik pada anak-anak maupun orang dewasa. Immunisasi dilakukan untuk menjaga kekebalan tubuh supaya tidak mudah terserang berbagai macam penyakit yang disebabkan oleh virus / bakteri.

Faktor lingkungan yang dinilai pada lingkungan rumah tempat tinggal anak yang mengalami ISPA meliputi ventilasi rumah, luas kamar, kelembapan, dan penerangan. Daerah rural merupakan salah satu penyebab untuk terjadinya ISPA karena masih tingginya pelayanan kesehatan dasar, kurangnya kesadaran penduduk, serta adanya faktor-faktor lain seperti status sosial ekonomi rendah dan masih banyaknya polusi udara dalam rumah. Selain itu, ventilasi yang baik sangat penting untuk menjamin ketersediaan dan mengalirkan udara dalam ruangan. Dengan adanya ventilasi yang baik akan memungkinkan pertukaran udara yang ada dalam rumah dengan udara luar

ISSN 2655-2434 
yang bersih, diharapkan mikroorganisme penyebab ISPA dapat keluar terbawa aliran udara. Selain itu dengan tidak memenuhinya standar ventilasi dapat membuat kelembaban udara dalam rumah kurang baik yang dapat menjadi tempat pertumbuhan dan perkembangan kuman patogen yang dapat mengakibatkan peningkatan risiko kejadian ISPA pada balita (Ramadhaniyanti, 2015). Lingkungan tempat penitipan anak, tinggal didaerah perkotaan yang padat dan sesak, penggunaan kayu bakar dalam rumah, dan tidur dilantai tanah, juga merupakan salah satu faktor penyumbang untuk terjadinya ISPA pada balita (Ujunwa, 2014)., Odu, (2018)., Chen et al, (2014). Berdasarkan teori agen biologis seperti bakteri, virus, riketsia, protozoa, metazoa merupakan kuman penyebab penyakit ISPA yang masuk dalam tubuh anak (Marni, 2014).

Lingkungan yang bersih dari debu dan tidak padat harusnya menjadi tempat tinggal yang baik bagi anak balita sehari-hari untuk mencegah terjadinya penyakit ISPA, karena salah satu penyebabnya yaitu karena udara yang dapat menjadi vektor untuk terjadinya penularan pada anak yang satu dengan lainnya. Faktor lingkungan fisik yang dapat mempengaruhi kesehatan adalah polusi. Marni (2014) menyatakan penyebab dari faktor polusi yaitu dengan menjaga kebersihan perorangan dan lingkungan. Membuat ventilasi udara serta pencahayaan udara yang baik akan mengurangi polusi asap dapur atau asap rokok yang ada di dalam rumah. Hal tersebut dapat mencegah seseorang menghirup asap yang bisa menyebabkan terkena penyakit ISPA. Ventilasi yang baik dapat memelihara kondisi sirkulasi udara (atmosfer) agar tetap segar dan sehat bagi manusia dan untuk mencegah anak berhubungan dengan penderita ISPA.

Infeksi saluran pernafasan akut (ISPA) ini disebabkan oleh virus/ bakteri yang ditularkan oleh seseorang yang telah terjangkit penyakit ini melalui udara yang tercemar dan masuk kedalam tubuh. Bibit penyakit ini biasanya berupa virus/bakteri di udara yang umumnya berbentuk aerosol (suspensi yang melayang di udara). Adapun bentuk aerosol yakni Droplet, Nuclei (sisa dari sekresi saluran pernafasan yang dikeluarkan dari tubuh secara droplet dan melayang di udara), yang kedua duet (campuran antara bibit penyakit) (Depkes RI tahun, 2012).Ventilasi yang baik berukuran $10 \%$ sampai

(C) PoltekkesKemenkes Jakarta I

Jl. WijayaKusuma No. 47-48 Cilandak Jakarta Selatan, Indonesia email: jurnalquality@ poltekkesjakarta1.ac.id
$20 \%$ dari luas lantai.Ventilasi yang baik akan memberikan udara segar dari luar, suhu optimum $22-24^{\circ} \mathrm{C}$ dan kelembapan $60 \%$, minimal cahaya yang masuk adalah lebih dari 60 lux dan tidak menyilaukan sehingga cahaya matahari dapat membunuh bakter-bakteri patogen (Rahayu, 2011). Untuk keperluan air minum dan masak air harus mempunyai persyaratan khusus agar air tersebut tidak menimbulkan penyakit bagi manusia (Notoatmodjo, 2003).

Penyakit ISPA disebabkan oleh bakteri atau virus yang masuk kesaluran nafas. Salah satu penyebab ISPA yang lain adalah asap pembakaran bahan bakar kayu yang biasanya digunakan untuk memasak. Asap bahan bakar kayu ini banyak menyerang lingkungan masyarakat, karena masyarakat terutama ibu-ibu rumah tangga selalu melakukan aktifitas memasak tiap hari menggunakan bahan bakar kayu, gas maupun minyak. Timbulnya asap tersebut tanpa disadarinya telah mereka hirup sehari-hari, sehingga banyak masyarakat mengeluh batuk, sesak nafas dan sulit untuk bernafas. Polusi dari bahan bakar kayu tersebut mengandung zat-zat seperti Dry basis, Ash, Carbon, Hidrogen, Sulfur, Nitrogen dan Oxygen yang sangat berbahaya bagi kesehatan (Depkes RI, 2010). Luas ruang tidur minimal 8 meter dan tidak dianjurkan digunakan lebih dari dua orang tidur dalam satu ruang tidur, kecuali anak dibawah 5 tahun (Depkes RI, 2012). Sebuah rumah yang memiliki kelembaban udara tinggi memungkinkan adanya tikus, kecoa dan jamur yang semuanya memiliki peran besar dalam pathogenesis penyakit pernafasan (Mahendrayasa 2018).

Peneliti menyadari bahwa penelitian ini memiliki keterbatasan yaitu tidak adanya instrumen penelitian yang standar yang dapat digunakan untuk mengetahui faktor yang mempengaruhi kejadian ISPA. Selain itu, instrumen ini baru satu kali diuji, meskipun dari hasil uji reliabilitas dan validitas baik. Populasi yang dipakai oleh peneliti hanya berdasarkan data register puskesmas, sementara ada penderita ISPA yang melakukan pengobatan ke fasilitas kesehatan lain, sedangkan jumlah sampel juga minimal dan kurang bervariasi dari segi karakteristik responden dalam penelitian sehingga hasil penelitian ini belum dapat mengeneralisasikan kejadian ISPA di wilayah kerja Puskesmas Perumnas. 


\section{SIMPULAN}

Hasil penelitian menunjukkan bahwa status imunisasi merupakan faktor yang paling berpengaruh untuk terjadinya penyakit ISPA pada balita di Wilayah Kerja Puskesmas Perumnas.

\section{SARAN}

Kepada keluarga yang memiliki anak balita diharapkan dapat meningkatkan pengetahuan tentang pencegahan sehingga dapat merawat anak yang mengalami ISPA dirumah dengan baik dan meningkatkan partisipasi dalam peran aktif mengikuti kegiatan posyandu balita untuk memantau kesehatan anak balita.

\section{Buku :}

\section{DAFTAR PUSTAKA}

Dharma, Kusuma Kelana (2012), Metodologi Penelitian Keperawatan : Panduan Melaksanakan Hasil Penelitian, Jakarta, Trans Info Media

Dinas Kesehatan Provinsi Bengkulu (2017). Profil Kesehatan Provinsi Bengkulu

Dinas Kesehatan Rejang Lebong (2018) Profil Kesehatan Rejang Lebong.

Irianto (2015). Memahami Berbagai Macam Penyakit. Bandung : Alfabeta

Kementerian Kesehatan RI. 2018. Laporan nasional RISKESDAS 2018.Jakarta:Balitban

Maharani, Dita; Fitri, Finny dan Lestari Yuniar (2013). Profil Balita enderita Infeksi Saluran Nafas Akut di Poliklinik Anak RSUP DR.M.Djamil Padang Tahun 20122013

Marni. (2014). Buku Ajar Keperawatan Pada Anak Dengan Gangguan Pernapasan. Yogyakarta: Gosyen Publishing.

Notoatmodjo, S. (2003). Pendidikan dan prilaku kesehtan. Jakarta : Penerbit PT. Rineka Cipta

Puskesmas Perumnas (2018). Buku Register Puskesmas Perumnas.

(C) PoltekkesKemenkes Jakarta I

Jl. WijayaKusuma No. 47-48 Cilandak Jakarta Selatan, Indonesia email: jurnalquality@poltekkesjakarta1.ac.id

\section{Artikel dan jurnal :}

Angelina, Rian. (2012). "Effect Of Total Quality Management, Reward Systems And Organization Commitment To Managerial Performance In Hospital In Pekanbaru”. Jurnal FE Universitas Riau

Chen, Y., Williams, E., dkk (2014). Risk Factors For Acute Respiratory Infection In The Australian Community.Journal Plos One https://journals.plos.org/plosone/article?id=1 0.1371/journal.pone.0101440

Depkes RI. (2010). Profil Kesehatan Indonesia. Jakarta. Tersedia :https://pusdatin.kemkes.go.id/article/vie w/13010200017/profil-kesehatanindonesia-tahun-2010.html

Depkes RI.(2012). Profil Kesehatan Republik Indonesia Tahun. 2012.(Online).Tersedia :http://www.depkes.go.id.30 januari 2019.

Dinkes RI. (2017). Profil Kesehatan Provinsi Bengkulu Tahun 2017. Dinas Kesehatan Provinsi Bengkulu

Dinkes RI. (2018). Profil Kesehatan Kabupaten Rejang lebong tahun 2018. Dinas Kesehatan Rejang Lebong. Kabupaten rejang Lebong.

Fuad (2008). Infeksi Saluran Pernapasan Akut (ISPA). Diakses dari fuafbahsin.wordpress.com. Diakses tanggal 24 Februari 2019 pukul 13.50 wib

Geberestsdik, A., Worku, dkk (2015). Factors Assocrated with Acute Respiratory Infection in Children Under The Age Of 5 Years : Evidance From The 2011 Ethiopia Demographic and Health Survey. Pediatric Health Medicine and Therapeutics

Maakh Y., F, Ivonne L, Rambu Tattu. Profil Pengobatan Infeksi Saluran Pernapasan Akut (ISPA) Pada Balita Di Puskesmas Rambangaru. Kupang. Jurnal Info Kesehatan Vol 15, No.2. Diakses tanggal 26 Februari 2019 Pukul 15.33 wib

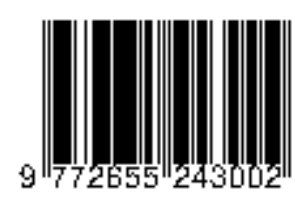


Mahendrayasa, dan Farapti. (2018). The Relationship between Household Physical Condition with Incidence of Toddler's Acute Respiratory Infection in Surabaya. Jurnal Berkala Epidomologi. Volume 06 No 03

Marlina, (2014). Hubungan dan Sikap Ibu Terhadap Kejadian ISPA pada Balita diwilayah Kerja Puskesmas Tigo Baleh Bukittinggi tahun 2014. Jurnal Keperawatan Stikes Yarsi Sumatra Barat Bukit Tinggi

Murti, Tri (2016). Faktor Resiko Kejadian ISPA pada Balita diwilayah Kerja Puskesmas Sukoharjo. Skripsi, Fakultas Ilmu Kesehatan, Jurusan Kesehatan Masyarakat, Universitas Muhamadiyah Surakarta

Murti, Tri (2016). Faktor Resiko Kejadian ISPA pada Balita diwilayah Kerja Puskesmas Sukoharjo. Skripsi, Fakultas Ilmu Kesehatan, Jurusan Kesehatan Masyarakat, Universitas Muhamadiyah Surakarta

Odu , Olugbenga Olusola ; Eyitope Oluseyi Amu 2 , Olusoji Abidemi Solomon 3 , James O Bamidele2 , Eyitayo Emmanuel 2, Stella Adetokunbo 4, Bayo D Parakoyi, (2018), Prevalence and risk factors of acute respiratory infection among under fives in rural communities of Ekiti State, Nigeria Oluremi Olayinka Solomon. http://gjmedph.com/uploads/O4Vo7No1.pdf

Rahayu Sri Yuyu. (2011). Kejadian Ispa Pada Balita Ditinjau Dari Pengetahuan Ibu, Karakteristik Balita, Sumber Pencemar Dalam Ruang Dan Lingkungan Fisik Rumah Di Wilayah Kerja Puskesmas Dtp Cibeber Kabupaten Lebak Propinsi Banten.

Rahmadaniyanti, N., Budiyono, Dkk. (2015). Faktor-Faktor Resiko Lingkungan Rumah Dan Perilaku Yang Berhubungan Dengan Kejadian Infeksi Saluran Pernafasan Akut (ISPA) Pada Balita Di Kelurahan

(C) PoltekkesKemenkes Jakarta I

J1. WijayaKusuma No. 47-48 Cilandak Jakarta Selatan, Indonesia email: jurnalquality@poltekkesjakarta1.ac.id
Kuninga Kecamatan Semarang Utara. Jurnal Kesehatan Masyarakat Volume 3, No 1, Januari 2015. Diakses https://media.neliti.com/media/publicatio ns/18420-ID-faktor-faktor-risikolingkungan-rumah-dan-perilaku-yangberhubungan-dengan-kejad.pdf

Ramezani, M., Aemmi, S. Z., Moghadam, Z. E. 2015. Factors Affecting the Rate of Pediatric Pneumonia in Developing Countries: a Review and Literature Study. Jurnal. Diakses pada tanggal 26 Februari 2019 http:// ijp.mums.ac.ir

Rehman, M.U, dkk (2018) Prevalence of acute respiratory infections (ARI) and its risk factors in under five children in urban and rural areas of Matta, district Swat. International Journal Of Infectious Diseases. Volume 73 No 1.

Selvaraj dkk, (2014).Acute respiratory infections among under-5 children in India: $A$ situationalanalysis. Tersedia : http://www.depkes.go.id.Diakses 7 Feb 2019 pukul 9.47 wib

Solomon, Odu, dkk (2018). Prevalence and risk factors of acute respiratory infection among under fives in rural communities of Ekiti State, Nigeria. Global Journal of Medicine and Public Health, 7(1), 1-12.

Tazinya, A. A., Halle-ekane, G. E., Mbuagbaw, L. T., Abanda, M., Atashili, J., \& Obama, M. T. (2018). Risk factors for acute respiratory infections in children under five years attending the Bamenda Regional Hospital in Cameroon. BMC Pulmonary Medicine, 18(7), 1-8. https://doi.org/10.1186/s12890-018-0579$\underline{7}$

Ujunwa Ezeonu; (2014). Risk Factors for Acute Respiratory Tract Infections in Under-five Children in Enugu Southeast Nigeria. https://www.researchgate.net/publication/ 261106506 Risk Factors for Acute Res piratory Tract Infections in Underfive_Children_in_Enugu_Southeast_Nige ria.

ISSN 2655-2434 
World Health Organization. (2007). Pencegahan

Dan Pengendalian Infeksi Saluran

Pernapasan Akut (ISPA87) Yang

Cenderung Menjadi Epidemi Dan

Pandemi Di Fasilitas Pelayanan

Kesehatan Pedoman Intermin WHO.

Diakses Dari

Https://Www.Who.Int/Csr/Resources/Pub

lications/WHO CDS EPR 2007 8bahas

a.Pdf 